\title{
Evaluation of Physical quality of alang-alang (Imperata cylindrical) fermentation as fed greenswamp buffalo
}

\author{
J Laksono $^{1^{*}}$ and W Ibrahim ${ }^{1}$ \\ ${ }^{1}$ Program Studi Peternakan Fakultas Peternakan, Universitas Musi Rawas \\ *Corresponding author: judolaksono@gmail.com
}

\begin{abstract}
The objectives of this study were to evaluate the physical quality of alang-alang (Imperata cylindrical) fermented using Banana Weevil Mol pH, color, aroma and texture. This research method using experimental methodswith completely randomized desig consists of 6 treatments repeated 3 times. . L1 : Banana Weevil Mol $20 \mathrm{ml} \mathrm{L2} \mathrm{:} \mathrm{Banana} \mathrm{Weevil} \mathrm{Mol} 25 \mathrm{ml}$ L3 : Banana Weevil Mol 30 ml L4 : Banana Weevil Mol 35 ml L5 : Banana Weevil Mol $40 \mathrm{ml}$ L6 : Banana Weevil Mol $45 \mathrm{ml}$.The results obtained were analyzed using analysis of variance and then the BNJ continued test. Based on the results of this study, it was shown that the physical quality of reeds fermented using banana weevil moles had a very significant effect ( $\mathrm{P}$ $<0.01)$ on $\mathrm{pH}$ parameters.significant effect $(\mathrm{P}<0.05)$ on color treatment and no significant effect $(\mathrm{P}>0.05)$ on aroma and texture treatment parameters.Based on the research, it can be concluded that evaluating the physical quality of Imperata in the $35 \mathrm{ml} \mathrm{L4:} \mathrm{Banana} \mathrm{Weevil}$ Mole treatment gave the best results in all observation parameters.
\end{abstract}

\section{Introduction}

Forage is one of the life sources for ruminants, because almost $80 \%$ of ruminansia feed consists of fresh forage. Livestock consume the forage like grass or legumes for maintenance of life, growth and development. According to [ 1 ],. Forage for livestock is the main source for the survival of ruminants. Avaibility of the forage can cause ruminant livestock development run well. Avaibility of feed continously in sufficient quallity and quantity are factors that can influence the ruminants productivity [ 2 ].

In Indonesia, the forage often encountered either on the side of the road, or on the land that is not utilized and it is known as alang-alang. Alang-alang or in latin call as Imperata cylindrica is a weed crop for farmers that growth very fast. Alang-alang can grow in areas with minimal nutrients. The nutritional of Imperata cylindrica, consists of $2.8 \%$ crude protein, $35.7 \%$ crude fiber, $5.42 \%$ ash, $3.6 \%$ extra active, $15.22 \%$ lignin, 44.28 cellulose $\%$, Hemi cellulose $28.58 \%$ [ 3 ].

The availability of a lot of reeds has a good enough potential to be developed into animal feed, especially buffalo cattle which are temporary against high crude fiber content. Imperata has a Lignin content of $15.22 \%$, this is a limiting digestion for ruminants For this reason, it is necessary to process it first so that the lignin content decreases by fermentation. Several ways to reduce high crude fiber are ammonia, silage and fermentation [ 4 ]. Fermentation is the preservation of feed ingredients derived from agricultural waste or forage with high enough crude fiber, so that an inoculum or decomposing microbes can be added to speed up the fermentation process. This study aimed to evaluate the physical quality of the fermented Imperata cylindrical 


\section{Materials and methods}

This research has been conducted in the Laboratory of the Faculty of Agriculture,Musi University Lubuklinggau Timur I Village, Lubuklinggau City, South Sumatra, with an altitude of 93 mdpl. The research took place from May to July 2020.

The materials used in this study are reeds that have not entered the flowering period, bran, molasses from agricultural stores, banana hump moles, water. While the tools used are the tools used are: coper machines, fakum machines, scales, ovens, plastics, measuring cups, $\mathrm{pH}$ meters, stationery.

This research was conducted using this research using experimental methods with a completely randomized design (CRD) consisting of 6 treatments, where each treatment was repeated 3 times. The treatment factors are as follows L1: $20 \mathrm{ml}$ Banana Weevil Mol L2: $25 \mathrm{ml}$ Banana Weevil Mol L3: 30 $\mathrm{ml}$ Banana Weevil Mol L4: $35 \mathrm{ml}$ Banana Weevil Mol L5: $40 \mathrm{ml}$ Banana Weevil Mol L6: $45 \mathrm{ml}$ Banana Weevil Mol

\section{RESULTS AND DISCUSSION}

The observation results of the physical test of the fermented Imperata cylindrical can be seen in the table. 1

Table 1. The results of the analysis of the physical test range for fermented Imperata cylindrical

\begin{tabular}{llll}
\hline No & Parameter & $\mathbf{F}_{\text {hitung }}$ & KK (\%) \\
\hline 1 & pH & $38,29^{* *}$ & 2,42 \\
2 & Color & $3,62^{*}$ & 4,73 \\
3 & Aroma & $1,11^{\text {th }}$ & 13,49 \\
4 & Texture & $2,61^{\text {tn }}$ & 6,69 \\
\hline
\end{tabular}

Information : $K K=$ Coefficient of Diversity

th $=$ Has no real effec

* = Have a real impact

** = Very Real Impact

Table 2.Data tabulation Results of analysis of variety Physical test of Imperata cylindrical

\begin{tabular}{llllllllll}
\hline No & Perlakuan & L1 & L2 & L3 & L4 & L5 & L6 & $5 \%$ & $1 \%$ \\
\hline 1 & $\mathrm{pH}$ & $5,0 \mathrm{cC}$ & $4,3 \mathrm{aA}$ & $4,3 \mathrm{aA}$ & $4,2 \mathrm{aA}$ & $4,3 \mathrm{aA}$ & $4,3 \mathrm{abAB}$ & 0,20 & 0,26 \\
2 & Color & $3,6 \mathrm{~b}$ & $3,5 \mathrm{~b}$ & $3,4 \mathrm{a}$ & $3,4 \mathrm{a}$ & $3,4 \mathrm{ab}$ & $3,1 \mathrm{a}$ & 0,31 & \\
3 & Aroma & 3,1 & 3,0 & 3,3 & 3,5 & 3,5 & 3,1 & & \\
4 & Texstur & 2,3 & 2,5 & 2,4 & 2,1 & 2,3 & 2,4 & & \\
\hline
\end{tabular}

Based on Table 1.Shows that the physical test of reeds (Imperata cylindrical) fermented has a very significant effect $(\mathrm{P}>0.01)$ on the $\mathrm{pH}$ parameter,significant effect $(\mathrm{P}<0.05)$ on color treatment and no significant effect $(\mathrm{P}>0.05)$ on the aroma and texture observation parameters.

\section{1. $\mathrm{pH}$}

Based on the analysis of variety, it shows that giving mole to Imperata fermentation has a very significant effect $(\mathrm{P}>0,01)$ against the reeds silage. This condition is caused by the presence of lactic acid bacteria and the presence of the ethanol oxidation process in fermentation to acetylldehyde which is then oxidized to lactic acid, so that this condition causes the fermentation process to become acidic. This is according to the opinion of [ 5 ], the acidic state of the fermentation results is caused by the oxidation of ethanol to acetidehydrate which then undergoes oxidation to become acidBased on the data above, the highest $\mathrm{pH}$ was in the $\mathrm{L} 1$ treatment with a value of 5.0 while the lowest $\mathrm{pH}$ value was in the L4 treatment with a value of 4.2. Whereas in these two treatments are acidic, so that the process involves a lot of lactic acid bacteria.. The resulting $\mathrm{pH}$ is below 4.0 which is acidic, so that in the 
process it involves many lactic acid bacteria which are formed from the anaerobic conditions of [ 6 ]. The acidic state in silage is due to the oxidation of ethanol to acetyldehyde which is then oxidized to lactic acid,This condition will cause the atmosphere to become acidic. This is in accordance with the opinion of [ 7 ]. that the acidic state of the silage fermentation is caused by the oxidation of ethanol to acetylldehyde which undergoes further oxidation to lactic acid.The picture of the influence of the banana hump mole can be seen in the picture. 1

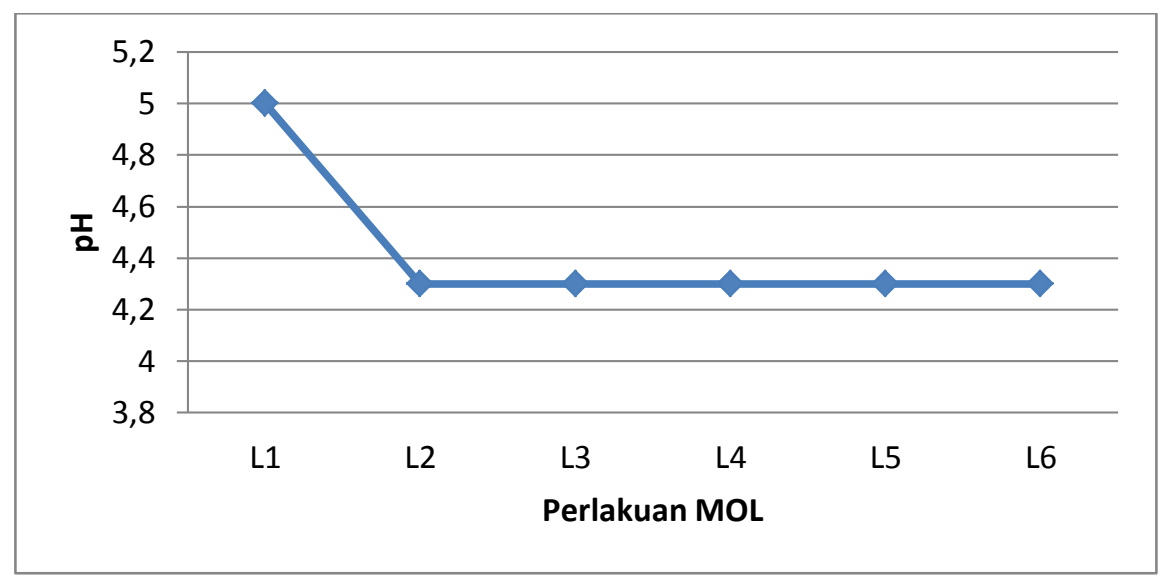

Picture. 1. The picture of the influence of the banana hump mole can be seen

\subsection{Color}

Based on the analysis of variety, it shows that the application of mole to Imperata fermentation has a significant effect $(\mathrm{P}<0,05)$ against the reeds silage. This is thought to be due to the degradation process of the lactic acid bacteria derived from the Mol so that it traps heat and causes a brown color change. This is in accordance with the opinion of [6]. in the fermentation process that uncontrolled temperature changes will occur which will cause the color change to light brown.Based on the data above, it can be seen that the highest value is in the L1 treatment with a value of 3.6, while the lowest is in the L6 treatment with a value of 3.6, this can be seen that the higher the dose given the color score will decrease, this is because LAB lacta acid bacteria originating from MOL banana hump.This is in accordance with the opinion of [ 8 ]. stated that lactic acid bacteria will convert glucose or simple carbohydrates into alcohol, acetic acid, carbonic acid and lactic acid. The picture of the influence of banana hump moles on color can be seen in the picture. 2

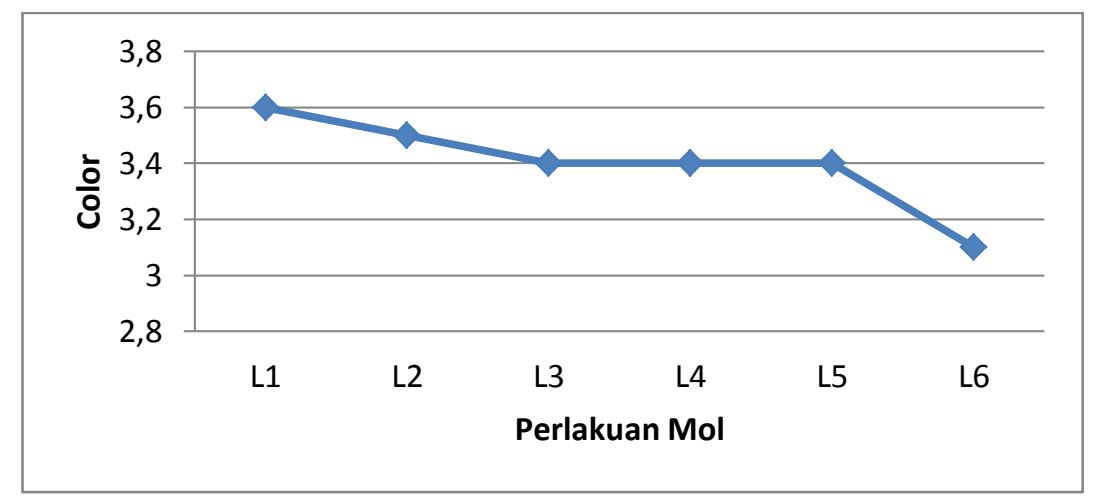

Picture.2 The image of the influence of banana hump moles on color can be seen 


\subsection{Aroma}

Based on the analysis of variance, it shows that giving mole to Imperata fermentation has no significant effect $(\mathrm{P}>0,05)$ against the reeds silage. This is presumably because the doses of moles that are almost the same in each treatment give an aroma that is not much different in each treatment where the aroma produced in this study tends to a fresh sour aroma,This fresh acid occurs due to the activity of anaerobic bacteria which actively work to produce organic acids, thus creating a fresh sour aroma. The process of this change is called ensilase, which occurs when oxygen is used up, plant respiration stops and the atmosphere becomes anaerobic [ 9 ]. Based on the data above, it can be seen that the highest value is in L5 treatment with a value of 3.5 while the lowest value is in L1 treatment. It can be seen that giving different banana hump moles results in a different aromaAccording to [ 10 ]. the sour aroma in silage is caused during the process of making silage, anaerobic bacteria actively work to produce organic acids and make the smell of silage sour, the smell of good silage smells sour and is not sharp.The picture of the influence of banana hump moles on aroma can be seen in the picture. 3

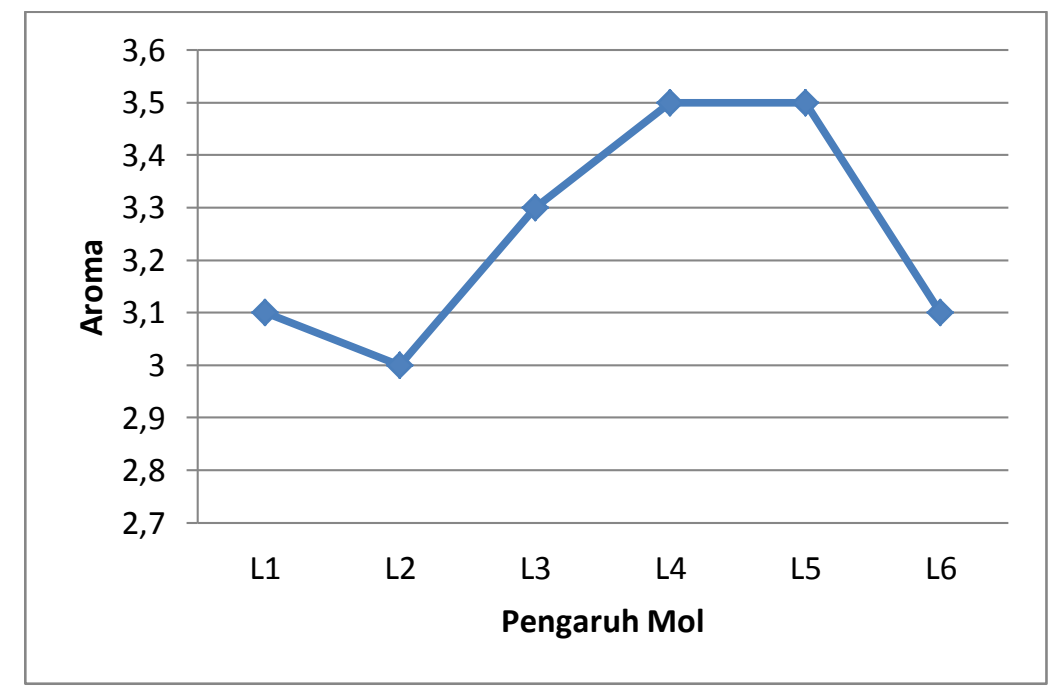

Picture.3 The image of the influence of banana hump moles on Aroma can be seen in the

\subsection{Texstur}

Based on the analysis of variance, it shows that giving mole to Imperata fermentation has no significant effect $(\mathrm{P}>0,05)$ against the reeds silage. This is presumably because the fermentation time of 21 days is not enough to change the texture of Imperata, although analysis of variance has no significant effect, there is a change in the texture of Imperata before fermentation is rather coarse and after fermentation it turns soft. this is due to an overhaul of the lignin, cellulose and silica bonds on the alang alang wall so that it becomes soft. The quality of fermentation also affects the quality of the ingredients, additives and fermentation time. This is in accordance with the opinion of [ 11 ], in general the quality of the silage used by the materials used, the air content, the particle size of the material, storage during the ensilase and the use of additives. Based on the tabulation data above, it can be seen that the highest value in texture in L2 treatment with a value of 2.5 and the smallest value in L4 treatment with a value of 2.1 this is because with $3.5 \mathrm{ml}$ moles of banana weevil it is able to change the texture of the grass to softThe picture of the influence of banana hump moles on tekstur can be seen in the picture 4 


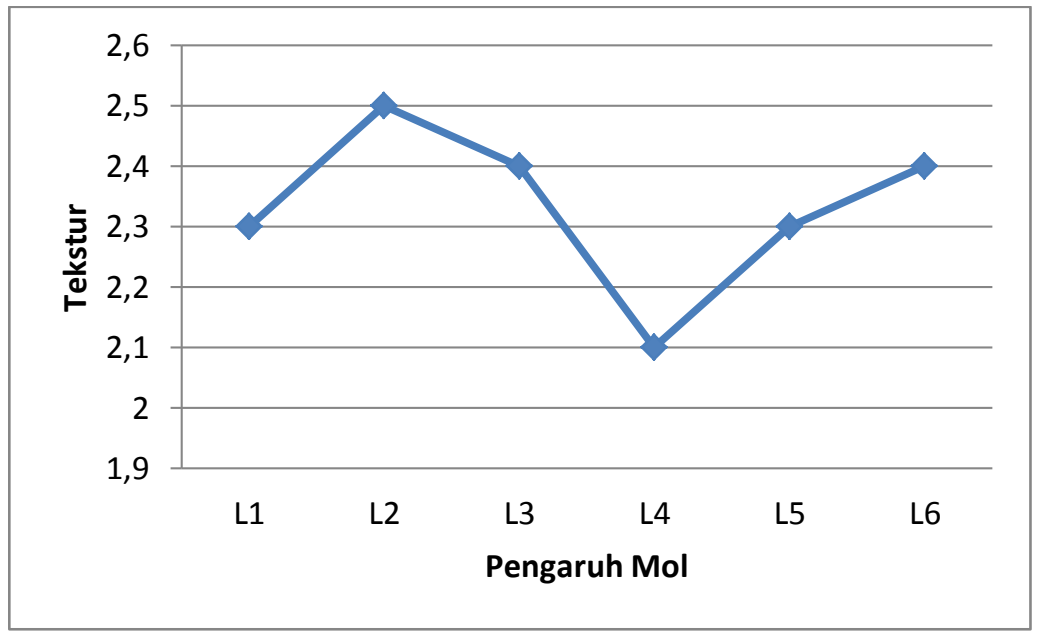

Picture.4. The image of the influence of banana hump moles on texture can be seen in the

\section{Conclusion}

Based on the results of the discussion of this study, it can be concluded that the physical test of alangalang-alang-alang imprata cylindrical fermented using Banana weevil mole gives a good value in the $35 \mathrm{ml}$ mole of banana weevil treatment. It is necessary to do further research on the analysis of the digestibility and level of palatability of livestock

\section{References}

[1] Laksono, J.,Ibrahim wasir2020 The Effect of Type and Dosage Manure on Vegetative Growth King Grass (Pennisetum purpuphoides)Journal of Livestock and Animal HealthVol. 3, No.1, : hal23-26

[2] Laksono, J.,T. Karyono. 2017 Administration of Albuscular Mycorrhizal Phosphates and Fungi on Plant Growth Legumindigofera zollingeriana. Jurnal Sain Peternakan Indonesia. 12:165170

[3] Wibisono, I. et al. 2011 „Pulping of Imperata J ofWidya Teknik, 10(1):11-20.Downloaded on :http://download.portalgaruda.org/article.Diakses pada Juli 2019

[4] Nurhayati, T., Y. Mas'udah, dan S. Sarudji. 2013. The Content of Crude Protein and Crude Fiber Palm Oil Fronds Fermented by Xylanolitic Bacteria(Bacilluspumilus)Agroveteriner. 1(2):73-78

[5] Sembayang, J.W.2004. Pembuatan Etanol dari Molases secara Fermentasi Menggunakan Sel Saccharomyces cerevisiae Trimobilisasi pada Kalsium Alginat. Jurnal Teknologi Proses 5 (2) $75-80$

[6] Sembayang, J.W.2004. Pembuatan Etanol dari Molases secara Fermentasi Menggunakan Sel Saccharomyces cerevisiae Trimobilisasi pada Kalsium Alginat. Jurnal Teknologi Proses 5 (2) $75-80$

[7] Laksono, J.,Ibrahim wasir2020 The Effect of Processing Method and Curing Time Oil Palm Fronds on The Swamp Buffalo (Buffelusasiaticus) Feed Nutrition Quality. Jurnal Ilmiah Peternakan Perpadu Vol. 8(1): 27-31, Maret 2020

[8] Kojo. 2015. The Effect of Addition of Rice Bran and Corn Flour on the Physical Quality of Elephant Grass Silage. Jurnal Zootek. Vol 35 (1) : 21-29

[9] Folley, R.C., Bath, D.L., Dickinson, F.Nand Tucker, H.A., 1972. DairyCattle: Principles, Practice.

[10] Kojo. 2015. The Effect of Addition of Rice Bran and Corn Flour on the Physical Quality of Elephant Grass Silage. Jurnal Zootek. Vol 35 (1) : 21-29

[11] Schroeder, J.W. 2004. Silage Fermentation and Preservation. Extension Dairy Specialist. AS- 
1254. 